\title{
Home oxygen therapy for acute bronchiolitis
}

\author{
Michael Sarrell E* \\ Pediatric Ambulatory Center, General Health Services, Petach Tikva, Israel
}

\begin{abstract}
Objective: To investigate the utility of home oxygen treatment for acute bronchiolitis in infants.

Design: Prospective, randomized, intent-to-treat.

Setting: Pediatric tertiary, university-affiliated medical center.

Patients: 135 children aged < 12 months who presented to an urban primary pediatric clinic in 2009-2011 with RSV bronchiolitis and mild to moderate hypoxia.

Interventions: Random allocation to three groups: Inhaled hypertonic or bronchodilator + supplemental oxygen ( $21 /$ min for 30 min 4 times daily) or bronchodilator only (control).

Main outcome measures: Number of emergency department visits and hospitalizations, number of lost days of daycare (infants) and work (parents), parental satisfaction, and changes in signs and symptoms.

Results: Background data were similar in all groups. Compared to the control group, oxygen-treated groups were characterized by a significantly shorter interval to normalization of respiratory rate and oxygen saturation $(p<0.001)$, significantly fewer hospital admissions $(p<0.0001)$, and emergency department referrals $(p$ $<0.001$ ), a significantly lower rate of chest infiltrates during follow-up $(p<0.0001)$, and fewer missed days of daycare and work $(p<0.0001)$. Rates of caregiver satisfaction were $88 \%$ and $78 \%$ in the oxygen-treated groups and $44 \%$ in the control group.
\end{abstract}

Conclusion: The administration of supplementary oxygen treatment at home in children aged < 12 months with RSV bronchiolitis is effective and safe, leading to a reduction in emergency department referrals and hospital admissions and an increase in caregiver satisfaction.

Abbreviations: Sign \& Symptoms Score: Bronchiolitis Sign and Symptoms Severity score; RSV: Respiratory Syncytial Virus; $\mathrm{SpO}_{2}$ : Oxygen Saturation measured by pulse oximetry; ED: Emergency Department; BCD: Bronchiolitis Caregiver Diary

\section{What is already known on this topic?}

Bronchiolitis is a leading illness in previously healthy infants. The outpatient care is inadequate in controlling the rate of emergency department and admission to the hospital.

\section{What does this study add?}

Short term home intermittent oxygen therapy to infants with RSV bronchiolitis in addition to other treatments modalities will reduce hypoxias and emergency department referrals, and in so hospitalization.

\section{Introduction}

Bronchiolitis is an infection of the bronchiolar epithelium. It is associated with profound submucosal and adventitial edema, increased secretion of mucus, and obstructed flow in the small airways, leading to hyperinflation, atelectasis, wheezing, and hypoxia. Respiratory syncytial virus (RSV) is responsible for the majority of cases $[1,2]$. Bronchiolitis is the most frequent lower respiratory tract infection in infants, resulting in high morbidity. The annual mortality rate ranges from 1.82 per 100,000 to 2 per 100,000 live births [1-3].

A recent review of hospitalization for infectious diseases in infants reported that the use of bronchodilators for RSV bronchiolitis led to short-term improvement in clinical scores but not in oxygenation or hospitalization rate [4]. Otherwise systemic glucocorticoids [5], antibiotics [5,6], furosemide [7], inhaled interferon alpha-2a (Roferon A) [8], and rhDNase [9] proved ineffective. Trials with chest physiotherapy using vibration and percussion techniques failed to reduce the severity of the illness, length of hospitalization, or oxygen requirements [10].

Antiviral agents (Ribavarin) are indicated only in children with a serious underlying disorder [11].

Treatment is mainly supportive, consisting of supplemental oxygen, suction, and hydration [12]. The goal is to reduce interference of hemoglobin oxygenation due to the airway edema and sloughing of the respiratory epithelial cells and the consequent ventilation/perfusion mismatch.

The administration of supplemental oxygen $\left(\mathrm{O}_{2}\right)$ in previously healthy children with bronchiolitis requires hospitalization. Advances in pulse oximetry technology have led to the detection of more and more cases of hypoxia in children [13], which keeps the high number of emergency department (ED) referrals and hospitalization. Several

*Correspondence to: Michael Sarrell E, 7 Ha'Iris St. Moshav Gan Hayim 44910, Israel, Tel: +972-9-7409610, Cell: +972-544289279; Fax: +972-97403196; E-mail: michaelsar@clalit.org.il

Key words: oxygen, supplemental, bronchiolitis, RSV, epinephrine, infants, randomized control trial, nebulized inhalation

Received: June 06, 2019; Accepted: June 25, 2019; Published: June 28, 2019 
investigators had shown that when supplemental $\mathrm{O}_{2}$ was used the overall admission rates for bronchiolitis was reduced in the ED [14], and hospital readmission was avoided [15], furthermore, early discharge from ED and hospital was possible [16]. At present, bronchiolitis is the leading cause of hospitalization in infants $[1,16]$. In developed countries, 30 per 1000 children in the first year of life are hospitalized annually for bronchiolitis. Of children who develop bronchiolitis during the first 2 years of life, approximately 1 in 10 (3\% of all infants in the USA) will be hospitalized [16,17]. Furthermore, in a substantial proportion of infants, the hospital stay until hypoxia improves may be prolonged [13], posing a further risk to these patients and increasing costs.

Prompted by these findings, we sought to determine if the number of ED referrals and hospitalizations of children with RSV bronchiolitis could be safely reduced by adding short-term home treatment with intermittent oxygen to the other treatments provided at the community primary care level.

\section{Methods}

\section{Patients}

The study population consisted of 135 infants aged less than 12 months who were treated for acute RSV bronchiolitis [functional oxygen saturation $\left.\left(\mathrm{SpO}_{2} \leq 95 \%\right)\right]$ in a pediatric ambulatory clinic in central Israel during the winter seasons of 2009 through 2011. The selection process is shown in figure 1 . Inclusion criteria for the study were $\mathrm{SpO}_{2} \leq 95 \%[15,18,19]$ by pulse oximetry (oximeter model 8500 ; Nonin Medical Inc., Minneapolis, MN) and respiratory rate (RR) $>45$ $\mathrm{bpm}$ in addition to a score of 9 or more on the Bronchiolitis Caregiver Diary (BCD) [20], a questionnaire of daily bronchiolitis sign and symptoms completed by caregivers of infants with bronchiolitis for rating the severity of episodes of coughing, wheezing, or wheezing with crackles and labored breathing due to respiratory effort, with or without chest recession $[9,20,21]$. Items are graded on a 6-point scale from 0 (no symptoms or interference) to 5 (very severe symptoms or interference); the maximum score is 20 . It has been found to have good interobserver reliability [20]. RSV positivity was confirmed by immunochromatographic assay of nasopharyngeal aspirate (ImmunoCard STAT-RSV, catalog no. 750930; Meridian Bioscience Europe, Villa Cortese, Italy). Infants with chronic diseases (e.g., cardiorespiratory disease, cystic fibrosis, neonatal asthma, malignancy) or immunodeficiency were excluded, as were infants who had received corticosteroids or bronchodilators in any form before presentation and infants whose parents refused to participate or were unable to complete the sign and symptoms BCD. Infants who had recovered from chronic neonatal lung disease of prematurity were included. The study was approved by the ethics (Helsinki) committee of the regional hospital. The parents of all participants provided written informed consent.

\section{Study design}

A prospective, randomized, intent-to-treat design was used all participants physician, nurse and parents were blinded to the randomization. Allocation of medication and tanks were concealed prior to randomization. After the parents signed the consent form, patients were randomly assigned to one of three treatment groups ( 45 patients each), as follows: (1) inhalation therapy with $2 \mathrm{ml}$ of $3 \%$ saline followed immediately by $2 \mathrm{l} / \mathrm{min}$ oxygen via nasal cannulae for $20 \mathrm{~min}$ ( ${ }^{*}$ oxygen hypertonic group); (2) inhalation therapy with nebulized 0.25 to 0.5 salbutamol diluted in $2 \mathrm{ml}$ of $0.9 \%$ saline followed immediately by $2 \mathrm{l} / \mathrm{min}$ oxygen via nasal cannulae for $30 \mathrm{~min}$ (oxygen treatment

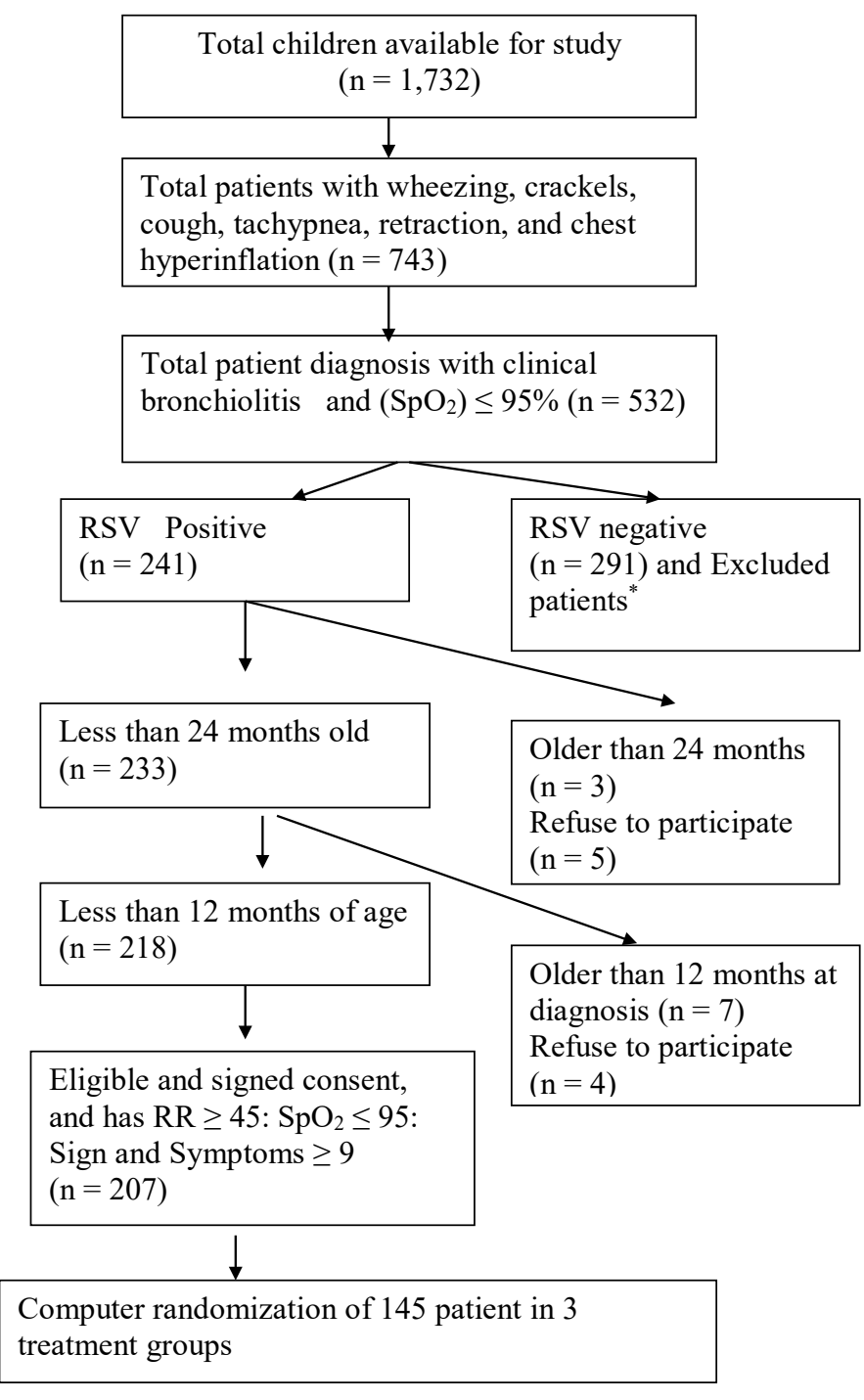

Figure 1. Flow of participants throw trail

group); (3) inhalation of nebulized 0.25 to $5 \mathrm{ml}$ salbutamol diluted in 2 $\mathrm{ml}$ of $0.9 \%$ saline (control group + room air filled tanks). Infant under 6 months received $0.25 \mathrm{ml}$ salbutamol, and age 6 to 12 months $0.5 \mathrm{ml}$. All protocols were administered 4 times daily at 6-hour intervals for 7 consecutive days.

\section{Procedure}

On admission day, the enrolling physician EMS measured the baseline $\mathrm{SpO}_{2}$ and $\mathrm{RR}$, while the research nurse recorded the values together with the signs and symptoms score on the BCD and administered the first treatment at the clinic, in accordance with the protocol to which the patient had been assigned. She then supplied the parents with numbered, marked, prefilled bottles and oxygen masks and tank (the control group tank were field with room air) and taught them how to administer the remaining treatments at home. The parents were instructed in standard supportive nasal suction for excess nasal secretions and rehydration, and were given written instructions describing the management of episodes of fever (rectal temperature $>$ $38.4^{\circ} \mathrm{C}$; acetaminophen alternating with ibuprofen $0.5 \mathrm{mg} / \mathrm{kg} /$ dose every 4 hours, as needed) and signs of a worsening condition: respiratory rate $>65$ breaths/minute, oxygen saturation $<85 \%$ or cyanosis, BCD score 
$\geq 13$ after oxygen treatment (including flaring nostrils and retraction of accessory muscles or appearance of lethargy, difficulties feeding (and fewer diaper changes). The parents and children returned to the clinic in the evening for repeated measurements.

Pulse oximetry was repeated twice daily, morning and evening, by the same physician, and the research nurse recorded the $\mathrm{SpO}_{2}$ at the same time points and measured the RR by stethoscope. At the end of each day, the parents again completed the sign and symptoms BCD.) After first treatment, the parents completed a 14 -item satisfaction questionnaire [21] which measures overall satisfaction with the quality of medical care received (4 items) and the appropriateness of the degree of the care received (4 items), their preference for home treatment ( 3 items), and satisfaction with the communication and thoroughness of the staff ( 3 items). Each item is scored a scale from 1 to 4 ; the maximum score is 56 . Chest $\mathrm{x}$-ray was performed on the $3^{\text {rd }}$ day to exclude bacterial pneumonia, foreign bodies, pulmonary edema, and other cardiac or respiratory tract abnormalities any prominent bronchiolar involvement, infiltrates or area of consolidation was consider pathological. After which the parents were asked whether they preferred that their infant be treated in hospital or at home. (The $3^{\text {rd }}$ day is known from our previous studies as the day most parents deiced on ED self referral if there was no improvement in the infant medical condition.)

Parents were advised to take the child to the ED at any time during the study, whenever they believed it necessary. The final decision was left to the parents because we sought to emulate a regular outpatient treatment course. We continued to follow any admitted infants during hospitalization. Patients were withdrawn from the study only if they had a life-threatening complication or allergic reaction to the medication.

\section{Definitions}

$\mathrm{SpO}_{2}$ on pulse oximetry accurately represents oxygen saturation $\left(\mathrm{SaO}_{2}\right)$, which is the percentage of hemoglobin saturated with oxygen at the time of measurement (oxyhemoglobin/total hemoglobin ratio). The median baseline value in healthy children during the first year of life is $97-100 \%[22,23]$. For the present study, $\mathrm{SpO}_{2}>95 \%$ was defined as acceptable saturation, $95 \%$ to $91 \%$ as mild desaturation, $90 \%$ to $80 \%$ as moderate desaturation, and less than $80 \%$ as severe desaturation. RR $\leq 35 \mathrm{bpm}$ or less was considered acceptable respiration, 35 to $45 \mathrm{bpm}$ as mild distress, 46 to $59 \mathrm{bpm}$ as moderate distress, and $60 \mathrm{bpm}$ or more as severe distress. A BCD score of $<4.5$ and a total satisfaction score of $>40$ after the $3^{\text {rd }}$ day was considered acceptable.

\section{Outcome measures}

Primary outcome measures of the study were number of emergency department visits and hospitalization admissions within 6 weeks of enrollment. Secondary outcome measures were changes in sign and symptoms $\mathrm{BCD}$ score, $\mathrm{RR}, \mathrm{SpO}_{2}$, and chest $\mathrm{x}$-ray findings. Tertiary outcome measures were daycare absences by infants, days of work missed by parents, and parental satisfaction with treatment.

\section{Sample size calculation}

The success rate for ED referral was estimated at $99 \%$. Using a minimum success rate of $90 \%$ the sample size necessary to detect a difference of half a standard deviation in ED referrals between the oxygen protocols and the control group at a significance level of $1 \%$ for two-sided tests with $90 \%$ power was calculated according to the formula for binominal proportions for independent samples [24]. The findings showed that we would require 135 infants, 45 in each of the 3 groups.

\section{Statistical analysis}

Data were analyzed with the SPSSWIN, version 19. Values were recorded as mean $+\mathrm{SD}$ and median differences in $\mathrm{BCD}$ score, $\mathrm{RR}$, $\mathrm{SpO}_{2}$, and parental satisfaction between time points were assessed using analysis of variance (ANOVA) with repeated measures. Differences in mean and median categorical variables among the treatment groups were analyzed by 2-tailed t-test for independent samples; noncontinuous variables (daily changes) were analyzed by chi-square or Friedman test. The Wilcoxon signed-rank test was used to evaluate changes in scores between groups and multiple comparisons was considered between the 3 groups. A 2-tailed p value of 0.05 was used to define statistical significance for differences between groups and to calculate confidence intervals around differences in sample means.

\section{Results}

Mean age of the 135 patients at diagnosis of RSV bronchiolitis was $4.7 \pm 2.6$ months (range 1-12 (95\% CI 4.1-6.9) There were no statistically significant differences among the three groups as they were randomly distributed in demographics, home environment, tobacco use at home, neonatal/prenatal complications, or medical history since birth (Table 1). There were also no significant differences among the groups in mean BCD score, RR, or $\mathrm{SpO}_{2}$ at baseline (Table 1 and Figure 2).

During the study, the hospital admission rate was $4.5 \%$ in the oxygen hypertonic group and $9.1 \%$ in the oxygen salbutamol group compared to $15.1 \%$ in the inhalation-only group $(p<0.001)$. The respective ED self-referral rates were $6.7 \%$ and $11.1 \%$ compared to $26.8 \%(p=$ 0.001) (Table 1). ED referrals and hospitalizations coincided with the appearance of infiltrates on chest $\mathrm{x}$-ray, found at rates of $8.9 \%$ in the oxygen hypertonic group and $13.3 \%$ in the oxygen salbutamol group compared to $33 \%$ in the inhalation-only group $(p<0.0001)$ (Table 1$)$.

When we analyzed the daily variability in parameter values, we found that BCD sign and symptoms scores dropped to mild $(<4.5)$ within 4 days in the oxygen hypertonic group (mean score $4.36 \pm 1.5$, $95 \%$ CI 3.9 - 4.81), 6 days in the oxygen salbutamol group (mean score $6.24 \pm 1.4,95 \%$ CI $5.83-6.66$ ), and 7 days in the inhalation-only group (mean score $7.1 \pm 1.9,95 \%$ CI $68-7.57$ ), statistically significant in each day and the time it took to reach an acceptable value $(p<0.001)$ (Figure 2 ). $\mathrm{RR}$ decreased over time, concomitant with an increase in $\mathrm{SpO}_{2}$. In the oxygen hypertonic group, mean RR measured $62.2 \pm 18.2 \mathrm{bpm}$ (95\% CI 60-64.5) at admission to $31.2 \pm 4 \mathrm{bpm}$ (95\% CI 30-32.4) on day 2. Corresponding values of $\mathrm{SpO}_{2}$ were $87.2 \pm 3.6 \%$ (95\% CI 86.188.3) and $95.2 \pm 1.5$ (95\% CI $95.1-95.8)$. The oxygen salbutamol group needed 3 days to reach a RR of $34.5 \pm 4.3 \mathrm{bpm}(95 \% \mathrm{CI} 33.2-35.8)$ and $\mathrm{SpO}_{2}$ of $95.6 \pm 1.4 \%(95 \% \mathrm{CI} 95.1-96.1)$. By contrast, the inhalationonly group needed 7 days to reach an RR of $34.6 \pm 5.6 \mathrm{bpm}(95 \% \mathrm{CI}$ $31.7-35.4$ ) and, even after 7 days, $\mathrm{SpO}_{2}$ measured only $94.1 \%$. Like for the sign and symptoms BCD score, the differences between each of the oxygen-treated groups and the non-oxygen-treated group were statistically significant $(p<0.001)$ (Figure 2).

The more rapid clinical improvement in respiratory status in the patients treated with oxygen resulted in significantly fewer missed days of daycare mean 2.18 in the oxygen hypertonic group; 4 in the oxygen salbutamol group, than in the inhalation-only group 5.62 days $(p<$ 0.0001 ). Accordingly, parents of infants in the oxygen-treated groups lost significantly fewer workdays (mean 2.25 and 3.37, respectively) than in the inhalation-only group (mean 4.5 days) $(p<0.0001)$ (Table 1$)$.

A satisfaction score above 40 on the $3^{\text {rd }}$ day was recorded by $88 \%$ $(40.2 \pm 1.2)$ of caregivers in the oxygen hypertonic group, and by $78 \%$ 


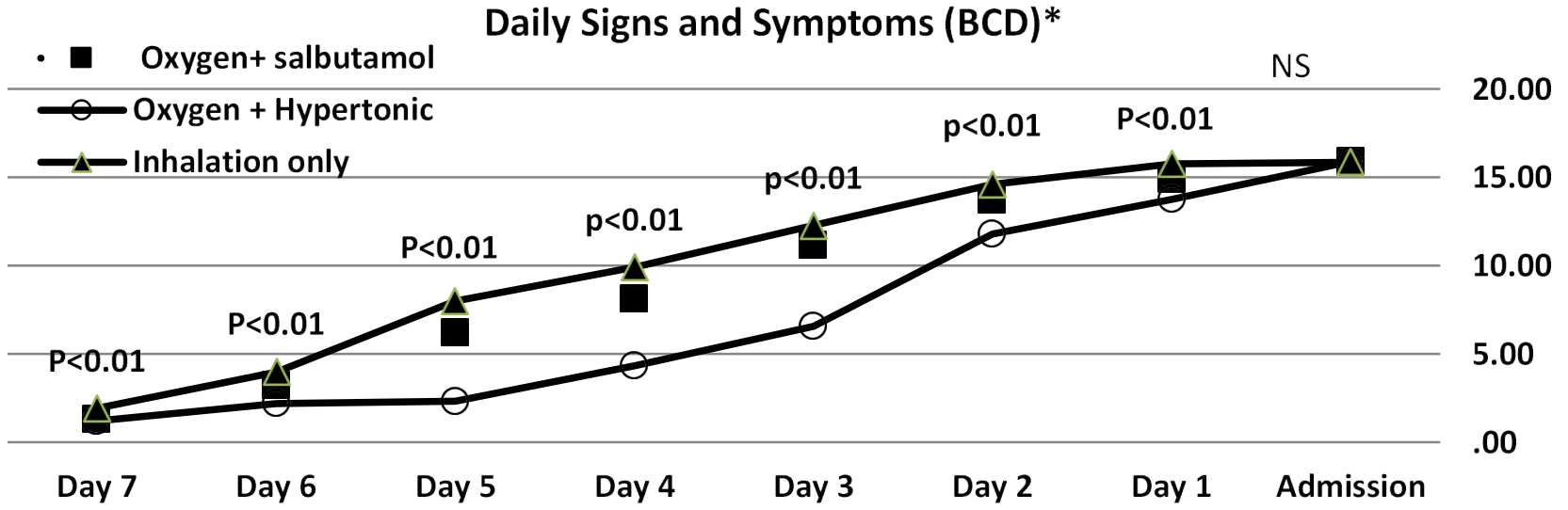

* C* Combeing mean score of daytime coughing, wheezing, trouble breathing related to respiratory effort, and nighttime coughing.

NS=Not Significant

\section{Respiratory Rate progression}

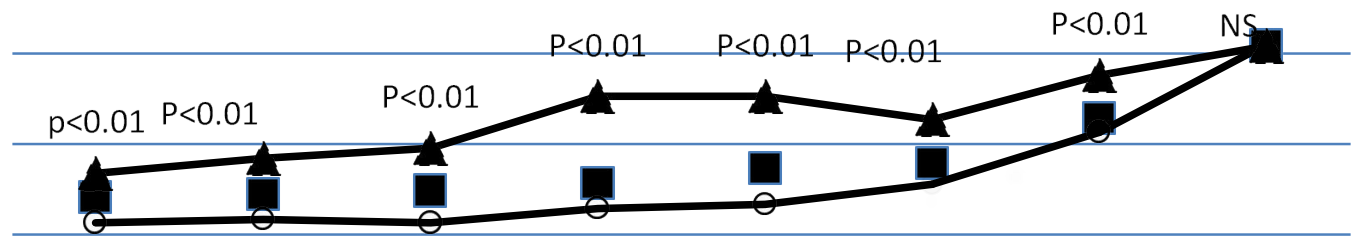

\begin{tabular}{|c|c|c|c|c|c|c|c|}
\hline Day 7 & Day 6 & Day 5 & Day 4 & Day 3 & Day 2 & Day 1 & Admission \\
\hline
\end{tabular}

- Oxygen+salbutamol - Oxygen + Hypertonic $\longrightarrow$ Inhalation only

\section{Oxigen Saturation (SpO2) progession}

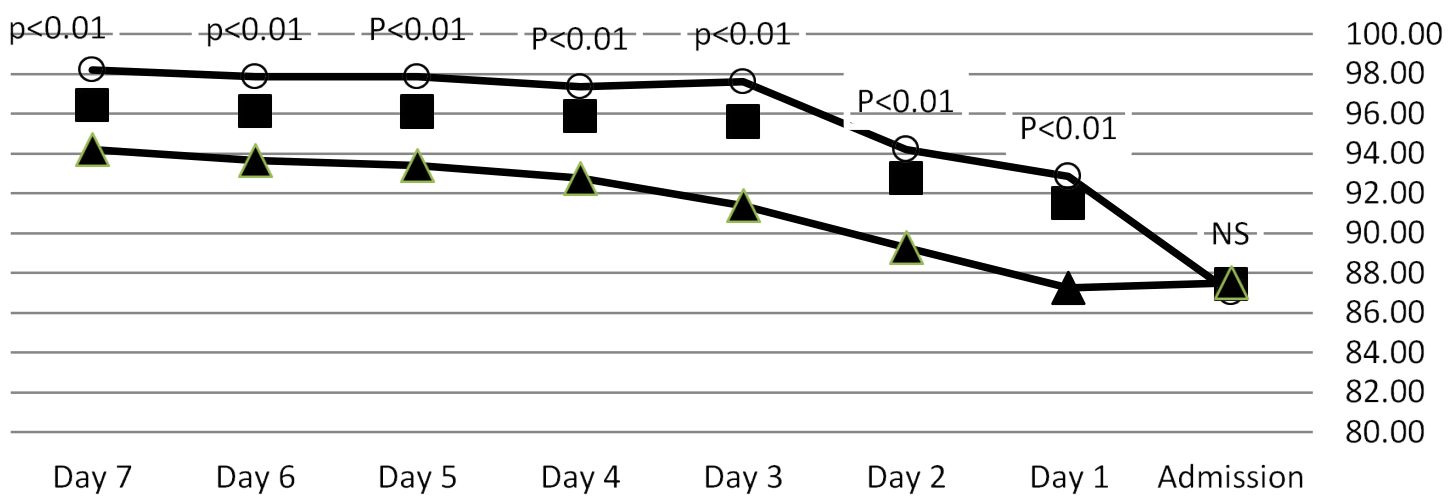

- Oxygen+salbutamol Oxygen + Hypertonic $\quad \longrightarrow$ Inhalation only 
Table 1. Background and clinical characteristics and outcome in infants with bronchiolitis treated with oxygen at home compared to controls

\begin{tabular}{|c|c|c|c|c|c|}
\hline & $\begin{array}{l}\text { Total No. } \\
(\%)\end{array}$ & $\begin{array}{l}\text { Hypertonic } \\
\text { 3\% saline } \\
\text { oxygen* } \\
(\mathbf{n}=45)\end{array}$ & $\begin{array}{l}\text { Salbutamol } \\
\text { inhalation } \\
\text { oxygen** } \\
(\mathbf{n}=45)\end{array}$ & $\begin{array}{l}\text { Salbutamol } \\
\text { inhalation } \\
\text { only }(n=45)\end{array}$ & $p$ Value \\
\hline & \multicolumn{5}{|c|}{ Medical History } \\
\hline Prenatal complications, $\mathrm{n}(\%)$ & $16(12)$ & $5(11)$ & $6(11)$ & $5(11)$ & 0.973 \\
\hline Neonatal/prenatal complications, n(\%) & $23(17)$ & $8(11.8)$ & $8(19.1)$ & $7(13.6)$ & 0.936 \\
\hline $\begin{array}{l}\text { Maternal smoking, } \mathrm{n}(\%) \\
\text { Admission Clinical presentation }\end{array}$ & $14(10)$ & $4(8.9)$ & $5(11.1)$ & $5(11.1)$ & 0.786 \\
\hline Temperature higher than $38.5^{\circ} \mathrm{C} \mathrm{n}(\%)( \pm \mathrm{SD})$ & $54(40)$ & $18(40 \%)( \pm 1.7)$ & $19(42 \%)( \pm 0.9)$ & $17(37.9 \%)( \pm 1.9)$ & 0.091 \\
\hline Pulse oximetry $\left(\mathrm{SpO}_{2}\right) \mathrm{n}( \pm \mathrm{SD})(\mathrm{CI})$ & $\begin{array}{l}87.3(+3.6) \\
(86.9-87.9)\end{array}$ & $\begin{array}{l}87.4(+3.61) \\
(86.1-88.6)\end{array}$ & $\begin{array}{l}87(+3.57) \\
(86.5-88.6)\end{array}$ & $\begin{array}{l}87.5(+3.64) \\
(86.3-88.9)\end{array}$ & 0.54 \\
\hline Respiratory rate bpm n $( \pm \mathrm{SD})(\mathrm{CI})$ & $\begin{array}{l}61.8( \pm 8.03) \\
(60.5-63.2)\end{array}$ & $\begin{array}{l}61.7( \pm 8) \\
(59.3-69.1)\end{array}$ & $\begin{array}{l}62( \pm 8.23) \\
59.7-69.6\end{array}$ & $\begin{array}{l}61.6( \pm 8.4) \\
(59.1-63.9)\end{array}$ & 0.972 \\
\hline \multirow[t]{2}{*}{$\begin{array}{l}\text { Bronchiolitis signs and symptoms } \\
\text { (BCD) mean } \pm \mathrm{SD}(\mathrm{CI})\end{array}$} & $\begin{array}{l}15.1(+1.21) \\
(14.82-15.97)\end{array}$ & $\begin{array}{l}15.3( \pm 1.3) \\
(15.1-16.3)\end{array}$ & $\begin{array}{l}15.1( \pm 1.29) \\
(14.8-16.4)\end{array}$ & $\begin{array}{l}14.9( \pm 1.33) \\
(14.3-15.98)\end{array}$ & 0.952 \\
\hline & \multicolumn{5}{|l|}{ Outcome } \\
\hline $\begin{array}{l}\text { Pathologic chest X-ray, mean } \pm \text { SD } \\
\text { (CI) }(\%)\end{array}$ & $25(18.5)$ & $\begin{array}{l}4( \pm 0.5) \\
(2.46-3.03) \\
(8.9 \%)\end{array}$ & $\begin{array}{l}6( \pm 1.43) \\
(3.01-4.02) \\
(13.3 \%)\end{array}$ & $\begin{array}{l}15( \pm 1.39) \\
(4.75-5.3) \\
(33 \%)\end{array}$ & $<0.0001$ \\
\hline $\mathrm{ED}$ referral, mean $\pm \mathrm{SD}(\%)$ & $20.6(15.2)$ & $\begin{array}{l}3.2(6.7 \%) \\
( \pm 1.4) \\
(4.3-5.6)\end{array}$ & $\begin{array}{l}5.3(11.1 \%) \\
( \pm 1.55) \\
(2.98-3.48)\end{array}$ & $\begin{array}{l}12.1(26.8) \\
( \pm 2.6) \\
(11.5-12.7)\end{array}$ & $=0.011$ \\
\hline $\begin{array}{l}\text { Hospitalized, mean }(\%) \pm \mathrm{SD} \\
\text { (CI) }\end{array}$ & $13.2(9.7)$ & $\begin{array}{l}2.3(4.5 \%) \\
( \pm 0.3) \\
(1.8-2.4)\end{array}$ & $\begin{array}{l}4.1(9.1 \%) \\
( \pm 1.08) \\
(3.41-4.02)\end{array}$ & $\begin{array}{l}6.8(15.1 \%) \\
( \pm 1.8) \\
(9.4-11.6)\end{array}$ & $<0.0001$ \\
\hline $\begin{array}{l}\text { Days missed by child, } \\
\text { mean }( \pm \mathrm{SD})(\mathrm{CI})\end{array}$ & & $\begin{array}{l}2.18( \pm 0.77) \\
(2.46-3.03)\end{array}$ & $4 \underset{( \pm 1.1)}{(3.6-4.3)}$ & $\begin{array}{l}5.62( \pm 1.23) \\
(4.75-5.3)\end{array}$ & $<0.0001$ \\
\hline $\begin{array}{l}\text { Parental work absence, } \\
\text { Mean } \pm \mathrm{SD},(\mathrm{CI})\end{array}$ & & $\begin{array}{l}2.25( \pm 1.34) \\
(2.0-2.51)\end{array}$ & $\begin{array}{l}3.37( \pm 1.3) \\
(2.9-3.89)\end{array}$ & $\begin{array}{l}4.5( \pm 1.73) \\
(3.99-4.62)\end{array}$ & $<0.0001$ \\
\hline $\begin{array}{l}\text { Caregiver satisfaction, } \mathrm{n}(\%) \\
\text { Mean } \pm \mathrm{SD}(\mathrm{CI})\end{array}$ & & $\begin{array}{l}40.2(88 \%) \\
( \pm 1.2) \\
(38.8-41.5)\end{array}$ & $\begin{array}{l}35.3(78 \%) \\
( \pm 1.7) \\
(33.7-36.8)\end{array}$ & $\begin{array}{l}20.2(44 \%) \\
( \pm 0.7) \\
(19.3-21.2)\end{array}$ & $<0.0001$ \\
\hline
\end{tabular}

$(35.3 \pm 1.7)$ of the caregivers in the oxygen salbutamol group. In the inhalation-only group, an acceptable satisfaction score was reported by only $44 \%(20.2 \pm 0.7)$ of the caregivers $(p<0.0001)$ (Table 1$)$. Home treatment by the end of the study was preferred by $84 \%$ of the caregivers in the oxygen hypertonic group and $73.5 \%$ in the + oxygen salbutamol group, compared to $22.2 \%$ in the inhalation-only group $(p<0.0001)$.

\section{Discussion}

This study suggests that the administration of oxygen treatment at home in children with uncomplicated RSV bronchiolitis is feasible and safe and can reduce the number of ED referrals and hospital admissions.

The present study assessed a relatively large sample of infants with RSV bronchiolitis, representing the largest and sickest group of children commonly admitted to hospital for treatment $[25,26]$. Earlier studies found that $57 \%$ of children hospitalized for bronchiolitis were younger than 6 months and $81 \%$ were younger than 1 year [25]. In our patients, the mean age was 4.7 months; all children were less than one year old. Others noted that the proportion of the one-year age group hospitalized for bronchiolitis increased from $22.2 \%$ in 1980 to $47.4 \%$ in 1996, commensurate with an increase in total hospitalizations for the same age group from $5.4 \%$ to $16.4 \%$, during the same period [25]. The need for oxygen was the major predictor for both hospital admissions and length of stay $[27,28]$. This finding was supported by Shay et al. [25] that calculated a 2.4-fold increase in hospital admission rates for bronchiolitis in children less than one year old (from 12.9 per 1000 in 1980 to 31.2 per 1000 in 1996), was directly related to severity of the illness and $\mathrm{SpO}_{2}$ level.
We speculated that home treatment with oxygen might alleviate at least part of this problem. Our results indicated that home oxygen therapy successfully increased $\mathrm{SpO}_{2}$ and reduced illness severity, thereby lowering the need for hospital admission for oxygen supplementation. Only $6.7 \%$ to $11.1 \%$ of all the children receiving oxygen visited the ED, of whom $4.5 \%$ to $9.1 \%$ were admitted. By contrast, among the children receiving standard salbutamol treatment, $26.7 \%$ visited the ED and $15.1 \%$ were admitted.

With the reduction in ED visits and hospital admissions, ill infants recovered more quickly and returned to daycare activity faster. Caregivers could then return to work earlier, which increased their satisfaction with the treatment and enhanced their trust in the recommendations of the medical staff. We did not directly study the economics of this practice, but earlier studies found that reducing admissions from $22 \%$ to $4.5 \%$ lowered costs. This is a substantial gain considering that the total annual cost for bronchiolitis-related hospitalizations in the USA in 2002 was 543 million dollars, with a mean of 3,799 dollars per hospitalization [25]. Studies from the United States estimated that the annual hospital costs for bronchiolitis ranged from at $\$ 365$ to $\$ 691$ million [4], with an overall cost of treatment of about $\$ 2.5$ billion per year [1]. Raut et al. [29] calculated a savings of 457 to 846 dollars for every one-half day decrease in hospital stay, or $\$ 500-900$ million dollars annually [30]. This does not take into account the savings to the total economy for each day the parent returns to work earlier and the savings to the individual household in medical expenses and productivity loss. The mean length of hospital stay for RSV bronchiolitis is 3.3 days [31], whereas our oxygen-treated patients spent 2.25 days in hospital. Thus, home care treatment in our study 
saved parents a full workday. Calculated household expenses for a sick child are approximately $\$ 538.75$ per sick day for a fully employed and insured caregiver and $\$ 424.83$ if one or more members is unemployed or uninsured [32].

Adjunctive treatment with nebulized bronchodilators remains controversial. Some researchers reported an association of bronchodilator use with improvement in the clinical score compared to placebo but not in-measures of oxygenation, rate of hospitalization, or length of hospital stay [33]. Others, however, noted a 9\%.

Hartling et al. [34] in a 2004 Cochrane review found insufficient evidence to support the use of bronchodilators for the in-hospital treatment of bronchiolitis. The use of salbutamol in the present study was based on earlier studies. The first showed that treatment with nebulized bronchodilators in an outpatient setting appears to lead to more rapid clinical improvement, thereby reducing the burden of care [35]. The second showed that the use of nebulized 3\% hypertonic saline solution treatment in ambulatory children with viral bronchiolitis [36], significantly shortened hospital stay and relieved symptoms and signs. These findings were later corroborated by others [37,38]. Most of the infants with mild hypoxia in our area treated in outpatient setting due to lack of hospital availability.

The rate of pathologic findings on chest radiographs in the present study was $20 \%$ in the inhalation-only group, $12.6 \%$ in the salbutamol oxygen group, and $9.3 \%$ in the hypertonic oxygen group. The finding in the latter group is in agreement with the study of Farah et al. [39] in which infiltration was noted in $17 \%$ of chest radiographs taken in children less than 12 months old with a first episode of wheezing during the RSV season.

The present study was limited by its small size, due to funding and operational constraints. Other limitations were short duration (7 days) and lack of data on repeated-dose pharmacokinetics, biological safety, and effect of prolonged use of the combined treatment. The short duration could also have reduced the statistical power to detect adverse events. Furthermore, randomization was not stratified by illness severity, so it is possible that one group contained more infants with severe illness than the others. It is also noteworthy that the results cannot be extrapolated to children aged more than 12 months or children with malnutrition, chronic illnesses, compromised immune function, congenital heart disease, or reinfection with RSV. We are also aware that the referrals to the ED and subsequent hospital admissions may have been affected by parental anxiety. We believe that some of the infants would not have been referred had the decision been left solely to the primary care physician.

In conclusion, home-administered oxygen treatment combined with bronchodilator or $3 \%$ hypertonic solution to carefully selected infants with mild to moderate acute bronchiolitis appears to improve clinical symptoms and the rate of chest complications, thereby reducing the rate of referrals to the ED and hospital admissions. Children return to daycare earlier and parental absenteeism from work is reduced. Intense primary care supervision is required for good results. Further in-depth studies in larger and more varied populations are needed to confirm these findings.

\section{References}

1. Leader S, Kohlase K (2003) Recent trends in severe respiratory syncytial virus (RVS) among US infants, 1997 to 2000. J Pediatr 143: S127-S132. [Crossref]

2. Fitzgerald DA, Kiham HA (2004) Bronchiolitis: assessment and evidence-based management. Med J Aust 180: 399-404. [Crossref]
3. Smyth RL, Openshaw PJ (2006) Bronchiolitis. Lancet 368: 312-322. [Crossref]

4. Yorita KL, Holman RC, Sejvar JJ (2008) Infectious disease hospitalization among infants in the United State. Pediatrics 121: 244-252. [Crossref]

5. Patel H, Platt R, Lozano JM, Wang EE (2004) Glucocorticoids for acute viral bronchiolitis in infants and young children. Cochrane Database Syst Rev CD004878. [Crossref]

6. Randolph AG, Reder L, Englund JA (2004) Risk of bacterial infection in previously healthy RSV infected young children admitted to the intensive care unit. Pediatr Infect Dis J 23: 990-994. [Crossref]

7. Van Bever HP, Desager KN, Pauwels JH, Wojciechowski M, Vermeire PA (1995) Aerosolized furosimide in wheezy infants: a negative report. Pediatr Pulmonol 20: 16-20. [Crossref]

8. Chipps BE, Sullivan WF, Porthnoy JM (1993) Alpha-2A-interferon for treatment of bronchiolitis caused by respiratory syncytial virus. Pediatr Infect Dis $J 12$ : 653-658. [Crossref]

9. Nasr SZ, Strouse PJ, Soskolne E, Maxvold NJ, Garver KA, et al. (2001) Efficacy of recombinant human deoxyribonuclease $\mathrm{I}$ in the hospital management of respiratory syccytial virus bronchiolitis. Chest 120: 203-208. [Crossref]

10. Perrotta C, Ortiz Z, Roque M (2005) Chest physiotherapy for acute bronchiolitis in paediatric patients between 0 and 24 months old. Cochrane Database Syst Rev 2 CD004873. [Crossref]

11. Hall CB (2001) Respiratory syncytial virus and parainfluenza virus. N Eng J Med 344 1917-1928. [Crossref]

12. Stang P, Brandenburg N, Carter B (2001) The economic burden of respiratory syncytial virusassociated bronchiolitis hospitalizations. Arch Pediatr Adolesc Med 155: 95-96. [Crossref]

13. Mallory MD, Shay DK, Garrett J, Bordley WC (2003) Bronchiolitis management preferences and the influence of pulse oximetry and respiratoty rate on the decision to admit. Pediatrics 111: e45. [Crossref]

14. Tie SW, Hall GL, Peter S, Vine J, Verheggen M, et al. (2009) Home oxygen for children with acute bronchiolitis. Arch Dis Child 94: 641-643 [Crossref]

15. Halstead S, Roosevelt G, Deakyne S, Bajaj L (2012) Discharged on supplemental oxygen from an emergency department in patients with bronchiolitis. Pediatrics 129 : e605-10. [Crossref]

16. Bajaj L, Turner CG, Bothner J (2006) A randomized trial of home oxygen therapy from the emergency department for acute bronchiolitis. Pediatrics 117: 633-640. [Crossref]

17. Gadomski AM, Bhasale AL (2006) Bronchodilators for bronchiolits. Cochrane Database Syst Rev 3: CD001266. [Crossref]

18. Sanchez-Menegay C, Hudes ES, Cummings SR (1992) Patient expectations and satisfaction with medical care for upper respiratory infections. $J$ Gen Intern Med 7 : 432-434. [Crossref]

19. Balfour-Lynn IM, Field DJ, Gringras P, Hicks B, Jardine E (2009) BTS guidelines for home oxygen in children. Thorax 64: ii1-ii26. [Crossref]

20. Santanello NC, Norquist JM, Nelsen LM, Williams VS, Hill CD, et al. (2005) Validation of pediatric care giver dairy to measure symptoms of postacute respiratoty syncytial virus bronchiolitis. Pediatr Pulmonol 40: 31-38. [Crossref]

21. Bharmal M, Payne K, Atkinson MJ (2009)Validation of an abbreviated Treatment Satisfaction Questionnaire for Medication (TSQM-9) among patients on antihypertensive medications. Health Qual Life Outcomes 7: 36.

22. Horenmuzova E, Katz-Salamon M, Mielerad J (2000) Breathing pattern, oxygen and carbon dioxide levels in sleeping healthy infants during the first nine months after birth Act Pedatric 89: 1284-1289. [Crossref]

23. Meyets I, Reempts PV, Boeck KD (2002) Monitoring of hemoglbine oxygen saturation in healthy infants using new generation pulse oximetry. Eur J Pediatr 161: 653-655.

24. Rosner B (1995) Fundaments of Bioststistics. 4th ed. Belmont CA: Duxbery Press p. 384.

25. Shay DK, Holman RC, Newman RD, Liu LL, Stout JW, et al. (1999) Bronchiolitisassociated hospitalizations among US children, 1980-1996. JAMA 282: 1440-1446. [Crossref]

26. Pelletier AJ, Mansbach JM, Camargo CA Jr. (2006) Direct medical costs of bronchiolitis hospitalizations in the United States. Pediatrics 118: 2418-2423. [Crossref]

27. Unger S, Cunningham S (2008) Effect of oxygen supplementation on length of stay for infants hospitalized with acute viral bronchiolitis. Pediatrics Pediatrics.121: 470-475. [Crossref] 
28. Plint AC, Johnson DW, Patel H, Wiebe N, Correll R, et al. (2009) Epinephrine and dexamethasone in children with bronchiolitis. N Eng J Med 360: 2079-2089. [Crossref]

29. Raut M, Schein J, Mody S, Grant R, Benson C, et al. (2009) Estimating the economic impact of a half-day reduction in length of hospital stay among patients with communityacquired pneumonia in the US. Curr Med Res Opin 25: 2151-2157. [Crossref]

30. Subcommittee on Diagnosis and Management of Bronchiolitis (2006) Diagnosis and Management of Bronchiolitis. Pediatrics 118: 1774-93. [Crossref]

31. Li S, Leader S (2007) Economic burden and absenteeism from influenza-like illness in healthy households with children (5-17 years) in the US. Respir Med 101: 1244-50. [Crossref]

32. Deshpande SA, Northern V (2003) The clinical and health economic burden of respiratory syncytial virus disease among children under 2 years of age in a defined geographical area. Arch Dis Child 88: 1065-1069. [Crossref]

33. Kellner JD, Ohlsson A, Gadomski AM, Wang EE (1999) Bronchodilators for bronchiolitis. Cochrane Database Syst Rev 1: CD001266. [Crossref]
34. Hartling L, Wiebe N, Russell K (2004) Epinephrine for bronchiolitis. Cochrane Database Syst Rev 1: CD003123. [Crossref]

35. Sarrell EM, Meyerovich J (2010) Epinephrine and bromhexine in the ambulatory treatment of bronchiolitis. J Ped infec Dis 377-384.

36. Sarrell EM, Tal G, Witzling M (2002) Nebulized 3\% hypertonic saline solution treatment in ambulatory children with viral bronchiolitis decreases symptoms. Chest 122: 2015-2020. [Crossref]

37. Villanueva P, Standish J, Douglas K, Mensah F, Jachno K, et al. (2011) Efficacy of hypertonic nebulized saline in bronchiolitis: Improved outcome measures needed. $J$ Pediatr 159: 353. [Crossref]

38. Luo Z, Fu Z, Liu E, Xu X, Fu X, et al. (2010) A randomized controlled trial of nebulized hypertonic saline treatment in hospitalized children with moderate to severe viral bronchiolitis. Clin Microbiol Infect 17: 1829-1833 [Crossref]

39. Farah MM, Padgett LB, McLario DJ, Sullivan KM, Simon HK (2002) First-time wheezing in infants during respiratory syncytial virus season: chest radiograph findings. Pediatr Emerg Care 18: 333-336. [Crossref]

Copyright: (C2019 Sarrell ME. This is an open-access article distributed under the terms of the Creative Commons Attribution License, which permits unrestricted use, distribution, and reproduction in any medium, provided the original author and source are credited. 